\title{
Milk production and composition, nitrogen utilization, and grazing behavior of late-lactation dairy cows as affected by time of allocation of a fresh strip of pasture
}

\author{
R. E. Vibart, ${ }^{*}$ M. Tavendale, ${ }^{*}$ D. Otter,† B. H. Schwendel, ${ }^{*}$ K. Lowe, ${ }^{*}$ P. Gregorini, $\ddagger$ and D. Pacheco ${ }^{* 1}$ \\ ${ }^{*}$ AgResearch, Grasslands Research Centre, Tennent Drive, Palmerston North 4442, New Zealand \\ †Center for Dairy Research, College of Agriculture and Life Sciences, University of Wisconsin-Madison, Madison 53706 \\ $\ddagger$ Agriculture and Life Sciences, Lincoln University, Lincoln 7647, Christchurch, New Zealand
}

\begin{abstract}
Eighty late-lactation dairy cows were used to examine the effects of allocating a new pasture strip of a sward based on ryegrass (Lolium perenne L.) in the morning (a.m.; $\sim 0730 \mathrm{~h}$ ) or in the afternoon (p.m.; $\sim 1530 \mathrm{~h}$ ) on milk production and composition, nitrogen $(\mathrm{N})$ utilization, and grazing behavior. Cows grazed the same pasture strips for $24 \mathrm{~h}$ and were offered the same daily herbage allowance. Herbage composition differed among treatments; p.m. herbage had greater dry matter (DM; 22.7 vs. $19.9 \%$ ), organic matter (OM; 89.5 vs. $88.9 \%$ ), and water-soluble carbohydrate (10.9 vs. $7.6 \%$ ) concentrations and lesser crude protein (20.5 vs. $22.2 \%)$ and neutral detergent fiber (48.8 vs. $50.4 \%$ ) concentrations compared with a.m. herbage. Total fatty acids (FA), $\alpha$-linolenic acid, and polyunsaturated FA (PUFA) were greater in a.m. herbage, whereas monounsaturated FA were greater in p.m. herbage. Estimates of herbage DM intake did not differ among treatments. Daily milk yields and milk fat and milk protein concentrations were similar among treatments, whereas milk fat (684 vs. $627 \mathrm{~g} / \mathrm{cow}$ ), milk protein (545 vs. $505 \mathrm{~g} / \mathrm{cow}$ ), and milk solids (milk fat + milk protein) yields $(1,228$ vs. $1,132 \mathrm{~g} / \mathrm{cow}$ ) tended to be greater for cows on p.m. herbage. Rumenic acid and total PUFA in milk were greater for cows on a.m. herbage, whereas oleic acid was greater for cows on p.m. herbage. Estimates of urinary $\mathrm{N}$ excretion $(\mathrm{g} / \mathrm{d})$ did not differ among treatments, but urinary $\mathrm{N}$ concentrations were greater for cows on a.m. herbage ( 5.85 vs. $5.36 \mathrm{~g} / \mathrm{L})$. Initial herbage mass (HM) available ( $\mathrm{kg}$ of $\mathrm{DM} / \mathrm{ha}$ ) and instantaneous HM disappearance rates $(\mathrm{kg}$ of $\mathrm{DM} / \mathrm{ha}$ and $\mathrm{kg}$ of $\mathrm{DM} / \mathrm{h}$ ) did not differ, but fractional disappearance rates $(0.56$ vs. 0.74 per hour for a.m. vs. p.m., respectively) differed. Under the current conditions, timing of pasture strip allocation altered the herbage nutrient supply to
\end{abstract}

Received December 6, 2016

Accepted March 21, 2017.

${ }^{1}$ Corresponding author: david.pacheco@agresearch.co.nz cows; allocating a fresh strip of pasture later in the day resulted in moderate increases in milk and milk solids yields in late-lactation dairy cows. Conversely, a greater concentration of precursor FA in a.m. herbage resulted in a greater concentration of beneficial FA in milk, compared with cows on p.m. herbage.

Key words: grazing management, time of herbage allocation, nitrogen utilization, milk fatty acids

\section{INTRODUCTION}

In New Zealand's pastoral dairy farming, nutrients supplied to dairy cows are largely derived from grazed herbage (Holmes et al., 2003; Macdonald et al., 2008), particularly from swards based on perennial ryegrass (Lolium perenne L.). Previous experiments (Cosgrove et al., 2007; Doreau et al., 2007) and modeling exercises (Ellis et al., 2009) have examined the effect of ryegrassbased diets with greater water-soluble carbohydrate (WSC) concentrations on lactation performance and N utilization. Dietary (i.e., plant) manipulation in these studies was largely via selective breeding (Miller et al., 2001; Taweel et al., 2006) and management-type approaches (Doreau et al., 2007). Among the grazing management strategies explored, diurnal accumulation of photosynthates accounted for consistent contrasts between WSC and CP concentrations in herbage (Mayland et al., 2005; Gregorini et al., 2008; Cosgrove et al., 2009).

The nutritive value of herbage from temperate swards often increases during the day (Burns et al., 2005; Gregorini et al., 2008), which is attributed to the diurnal processes of plant photosynthesis and transpiration. Dry matter and WSC accumulate during the day (Mayland et al., 2005; Gregorini et al., 2008), often diluting fiber and $\mathrm{N}$ concentrations of herbage DM (Delagarde et al., 2000) and enhancing digestibility (Abrahamse et al., 2009) and palatability (Fisher et al., 1999). Also, from dawn to dusk, herbage biomechanical properties (i.e., reduced toughness) enhance the feeding value for herbage consumed during dusk (Gregorini et 
al., 2009b). These diurnal changes affect the temporal pattern of herbage intake and alter the ingestive and digestive behavior of grazing ruminants (Gibb et al., 1998; Orr et al., 2001; Gregorini, 2012).

The consumption of a more balanced fermentable carbon to nitrogen $(\mathrm{C}: \mathrm{N})$ ratio from herbage can potentially enhance herbage DMI, milk yield, and $\mathrm{N}$ utilization in grazing dairy cows, particularly those in late lactation (Miller et al., 2001; Cosgrove et al., 2007; Brito et al., 2008). Increases in milk production have been attributed to greater digestible DMI (Miller et al., 2001; Brito et al., 2008) and total DMI (Brito et al., 2008). These studies, however, included indoor (Miller et al., 2001) and baleage feeding (Brito et al., 2008) rather than grazing (Cosgrove et al., 2007). However, no intake measurements or estimates were reported in the latter study.

Feeding fresh grass is an efficient way of increasing the content of beneficial fatty acids (FA) in milk, such as n-3 FA and rumenic acid (the major conjugated linoleic acid CLA isomer C18:2 cis-9,trans-11) (Elgersma, 2015). Despite extensive ruminal biohydrogenation, the amount and quality of herbage consumed, and more specifically, the concentration and fate of FA in feed, digestive tract, and mammary gland, determine the FA profile in milk. Although extensive reviews on FA profiles of milk fat (including those originating from rotational grazing systems) have been published (e.g., Glasser et al., 2013; Elgersma, 2015), the effect of time of allocation of a fresh strip of grass on the FA profile of milk remains to be elucidated.

We hypothesized that late-lactation dairy cows with access to a new pasture allocation (sole diet) after the afternoon milking produce more milk and milk solids while having improved overall $\mathrm{N}$ utilization. The objective of this study was to examine the effects of allocating a 24-h strip of fresh herbage from a ryegrass-based pasture either in the morning or in the afternoon on milk production and milk composition (with an emphasis on FA concentrations), $\mathrm{N}$ utilization, and grazing behavior in late-lactation dairy cows.

\section{MATERIALS AND METHODS}

\section{Research Site, Cows, and Pastures}

The experiment was conducted at the Massey University No. 4 Dairy farm $\left(40^{\circ} 19^{\prime} \mathrm{S}, 157^{\circ} 37 \mathrm{E}\right.$; Palmerston North, New Zealand) during April and May 2010. The research site is located on Tokomaru silt loam soils, defined as Aeric Fragiaqualfs with poor natural drainage, at an elevation of $60 \mathrm{~m}$ above sea level, with an average annual rainfall of approximately 1,000 $\mathrm{mm}$. Weather data were obtained from a weather station located in the proximity of the research site (AgResearch, Grasslands Research Centre, Palmerston North).

Eighty lactating cows (Holstein Friesian $\times$ Jersey crosses) averaging [mean \pm standard deviation (SD)] $463 \pm 46.8 \mathrm{~kg}$ of BW, $224 \pm 21 \mathrm{DIM}$, and $12.2 \pm$ $2.1 \mathrm{~kg}$ initial milk yield were used in this experiment. Cows were blocked by milk yield, parity, and DIM and randomly assigned to either a morning (a.m.; 0730 $\mathrm{h}$, following the morning milking) or an afternoon (p.m.; $1530 \mathrm{~h}$, following the afternoon milking) new pasture strip allocation. Corresponding milking times were approximately $0630 \mathrm{~h}$ and $1430 \mathrm{~h}$. Each allocation treatment included 2 herds of 20 cows each (40 cows per treatment). At any given time, all herds (i.e., groups of cows) grazed side-by-side within the same pre-assigned paddock; herds were randomly assigned to strips within paddocks (4 strips per day). Seven paddocks, comprising a total area of 14.5 ha, were used throughout the experiment. The experiment included a period of adaptation (14 d) followed by a period of data collection (14 d). Cows were individually weighed (TruTest, Auckland, New Zealand) after morning milking, once during the adaptation period, and twice during the data collection period. Procedures performed during this experiment were approved by the Grasslands Animal Ethics Committee (Approval No. 12054).

\section{Herbage Intake}

Experimental paddocks were rotationally grazed (strip-grazed) with the aid of temporary electric fences. Cows grazed the same strip for a 24-h period and were offered the same daily DM allowance, with a targeted daily herbage DMI of $16 \mathrm{~kg}$ per cow (sole diet; calculated from clippings to a $4-\mathrm{cm}$ height). The area offered daily per herd was calculated based on the daily herbage DMI target $(\mathrm{kg} / \mathrm{cow})$, pregrazing herbage mass (HM) and postgrazing HM (preHM and postHM, respectively) according to the following equation:

$$
\begin{gathered}
\text { Area offered daily }(\text { ha })=(\text { cows per herd } \\
\times \text { target DMI }) /(\text { preHM }- \text { postHM })
\end{gathered}
$$

Pre- and postgrazing HM were determined using an electronic rising plate meter (Farmworks Precision Farming Systems, Feilding, New Zealand), according to $[\mathrm{HM}, \mathrm{kg}$ of $\mathrm{DM} / \mathrm{ha}=(158 \times$ herbage height, $\mathrm{cm})$ $+200]$. The values recorded with the plate meter were the mean of approximately 50 readings taken randomly throughout the area allocated for grazing by each herd daily. Estimates of daily herbage intake were obtained 
by difference between pre- and postgrazing HM (Macoon et al., 2003). This methodology only provides an average estimate of DMI for each treatment, with paddock (i.e., estimates from 7 different paddocks), rather than the individual animal, as the experimental unit, according to the following equation:

$$
\begin{gathered}
\mathrm{DMI}(\mathrm{kg} \text { of DM } / \mathrm{cow})=[(\operatorname{preHM}-\text { postHM }) / \\
\text { cows per herd }] \times \text { area offered }(\text { ha }) .
\end{gathered}
$$

\section{Milk Production and Milk Composition}

Milk yields were recorded automatically at every milking (Alpro, DeLaval, Tumba, Sweden). Milk samples were collected from each cow during the afternoon and following morning milking event 3 times (once during the adaptation period and twice during the data collection period; d 0, d 16, and d 23) and analyzed for fat, $\mathrm{CP}$, lactose, and MUN concentrations and somatic cell counts. Milk samples were collected from proportional in-line samplers and immediately refrigerated at $4^{\circ} \mathrm{C}$ after collection until processing in the laboratory (i.e., Cosgrove et al., 2007). Milk fat, CP, and lactose composition were obtained using a FT 6000 Fourier Transform infrared analyzer (TestLink, Hamilton, New Zealand). Milk urea concentration was determined in milk supernatant by a urease-UV procedure, using a Flexor E clinical chemistry analyzer (Vital Scientific, Dieren, the Netherlands) and a commercial diagnostic kit for urea (Roche Diagnostic NZ Ltd., Mt. Wellington, Auckland, New Zealand) according to recommendations from the manufacturer. Daily milk solids yield (MSY; fat + protein) was calculated using the concentration of fat and $\mathrm{CP}$ and the milk yields measured on the days of sample collection. Nitrogen secreted in milk was estimated as milk CP yield divided by 6.38 .

Milk FA analysis was conducted as described by Schwendel et al. (2015). Briefly, the method by Toledo et al. (2002) was modified to account for a smaller milk sample volume $(1 \mathrm{~mL})$. Samples were extracted with 2-propanol $(2 \mathrm{~mL})$ and hexane $(1.5 \mathrm{~mL})$, which contained $\left[1,1,1-{ }^{13} \mathrm{C}\right]$ trioctanoin (Larodan Fine Chemicals, Solna, Sweden) as an internal standard. The hexane layer was then dried under $\mathrm{N}_{2}$ and the milk fat was dissolved in hexane $(1 \mathrm{~mL})$ before the addition of 0.1 $M \mathrm{KOH}$ in methanol $(2 \mathrm{~mL})$. Next, tubes were sealed and heated for $1 \mathrm{~h}$ at $50^{\circ} \mathrm{C}$ to facilitate the trans-esterification process of glycerides into the corresponding FAME. The resulting mixture was neutralized with 0.1 $M \mathrm{HCl}$. The organic solvent layer containing FAME was diluted 1:1 (vol:vol) with hexane and injected into a GC-MS (Shimadzu GC-17A QP5050A, Shimadzu,
Kyoto, Japan). The FAME were separated on a $60-\mathrm{m}$ SGE BPX 70 column (i.d. $0.25 \mathrm{~mm}$; film thickness $0.25 \mu \mathrm{m} ; 60 \mathrm{~min}$ run time). Injection port and interface temperatures were maintained at $240^{\circ} \mathrm{C}$, and the column temperature profile was similar to Schwendel et al. (2015), with helium used as the carrier gas. Fortynine FAME were identified via retention time and their characteristic ion responses and quantified relative to the internal standard and their corresponding response obtained from the concurrent analysis of an external standard (Supelco FAME Mix C4-C24; Sigma-Aldrich, St. Louis, MO). Fatty acids are expressed as grams per $100 \mathrm{~g}$ of total FA.

\section{Urinary Nitrogen}

In concurrence with the last 2 milk sampling periods, urine samples were collected immediately before, during, and after morning and afternoon milking to estimate urinary N excretion. Spot urine samples were collected from all cows; a representative sample of midstream urination was collected by 5 independent observers. To induce urination, a stimulatory vulvar massage was applied to the minority of cows that did not urinate voluntarily. Urine samples were collected in a plastic container and immediately placed in ice until further processing and analyses. Immediately after collection, subsamples were used for creatinine analysis; urinary creatinine concentration was obtained using a spectrophotometric assay, a compensated Jaffe reaction in a Hitachi 902 automatic analyzer (NZ Veterinary Pathology, Palmerston North, New Zealand). Urine samples were acidified $\left(30 \mathrm{~mL}+250 \mu \mathrm{L}\right.$ of $\left.6 \mathrm{M} \mathrm{H}_{2} \mathrm{SO}_{4}\right)$ and stored frozen $\left(-20^{\circ} \mathrm{C}\right)$ until further analysis. Total urinary $\mathrm{N}$ concentration was obtained using a combustion method (Carlo Erba Nitrogen Analyzer; Carlo Erba, Cornaredo, Italy).

Urinary $\mathrm{N}(\mathrm{g} / \mathrm{d})$ was estimated using 2 prediction models:

(a) From urinary creatinine in spot samples, using a creatinine excretion factor of $21.9 \mathrm{mg} / \mathrm{kg}(\mathrm{Pa}-$ checo et al., 2007), according to the following equation:

$$
\begin{gathered}
\mathrm{N} \text { in urine }(\mathrm{g} / \mathrm{d})=[(21.9 \times \mathrm{BW}, \mathrm{kg}) / \\
\text { urinary creatinine, } \mathrm{mg} / \mathrm{kg}] \times \text { urine } \mathrm{N}(\mathrm{g} / \mathrm{kg})
\end{gathered}
$$

(b) From MUN concentration according to the equation of Jonker et al. (1998):

$\mathrm{N}$ in urine $(\mathrm{g} / \mathrm{d})=12.54 \times \mathrm{MUN}(\mathrm{mg} / \mathrm{dL})$. 


\section{Grazing Behavior}

The temporal grazing pattern was recorded by trained observers during two 24-h periods, on d 16 and d 22 of the experiment. Grazing and nongrazing activities were recorded every $5 \mathrm{~min}$, which is within the time range of visual grazing time measurements reported by Bargo et al. (2003). For the purpose of this study, grazing was defined as cows head down, in contact with the sward, and engaged in acquiring herbage into the mouth, whereas nongrazing included all other activities (i.e., searching, ruminating, idling). From these data, total grazing time was calculated by multiplying each grazing activity (i.e., proportion of cows grazing at any given time) by a 5 -min interval (Figure 1). Herbage disappearance during these periods was assessed by using a rising plate meter (Farmworks Precision Farming Systems) at set time intervals (immediately before grazing, and every $30 \mathrm{~min}$ thereafter up to $4 \mathrm{~h}$ after commencement of the main grazing events; at $0730 \mathrm{~h}$ for cows on a.m. herbage and at $1530 \mathrm{~h}$ for cows on p.m. herbage). Plate meter readings followed the same transect in all recordings. Herbage mass disappearance rate was cal- culated from HM measurements using the fractional disappearance model of Ørskov and McDonald (1979) adapted to grazed HM disappearance (Gregorini et al., 2009a). Herbage mass disappearance rate was obtained by fitting HM data $(y)$ from each grazed strip into the following equation:

$$
y=a-b \times[1-\exp (-c \times \text { time })]
$$

where $a=$ pregrazing, available HM ( $\mathrm{kg}$ of DM/ha); $b=$ potential HM disappearance ( $\mathrm{kg}$ of $\mathrm{DM} / \mathrm{ha})$; and $c=$ fractional disappearance rate of HM (per hour). Time was set at $0,60,120,180$, and 240 min after commencement of the main grazing events. Instantaneous $\mathrm{HM}$ disappearance rates ( $\mathrm{kg}$ of $\mathrm{DM} /$ ha per hour) were estimated as the first derivative of the function $[y=-b$ $\times c \times \exp (-c \times$ time $)]$ for the same time points mentioned above, as outlined by Gregorini et al. (2009a).

\section{Pasture Chemical Composition}

Concurrently with the HM disappearance assessment, herbage samples were collected immediately

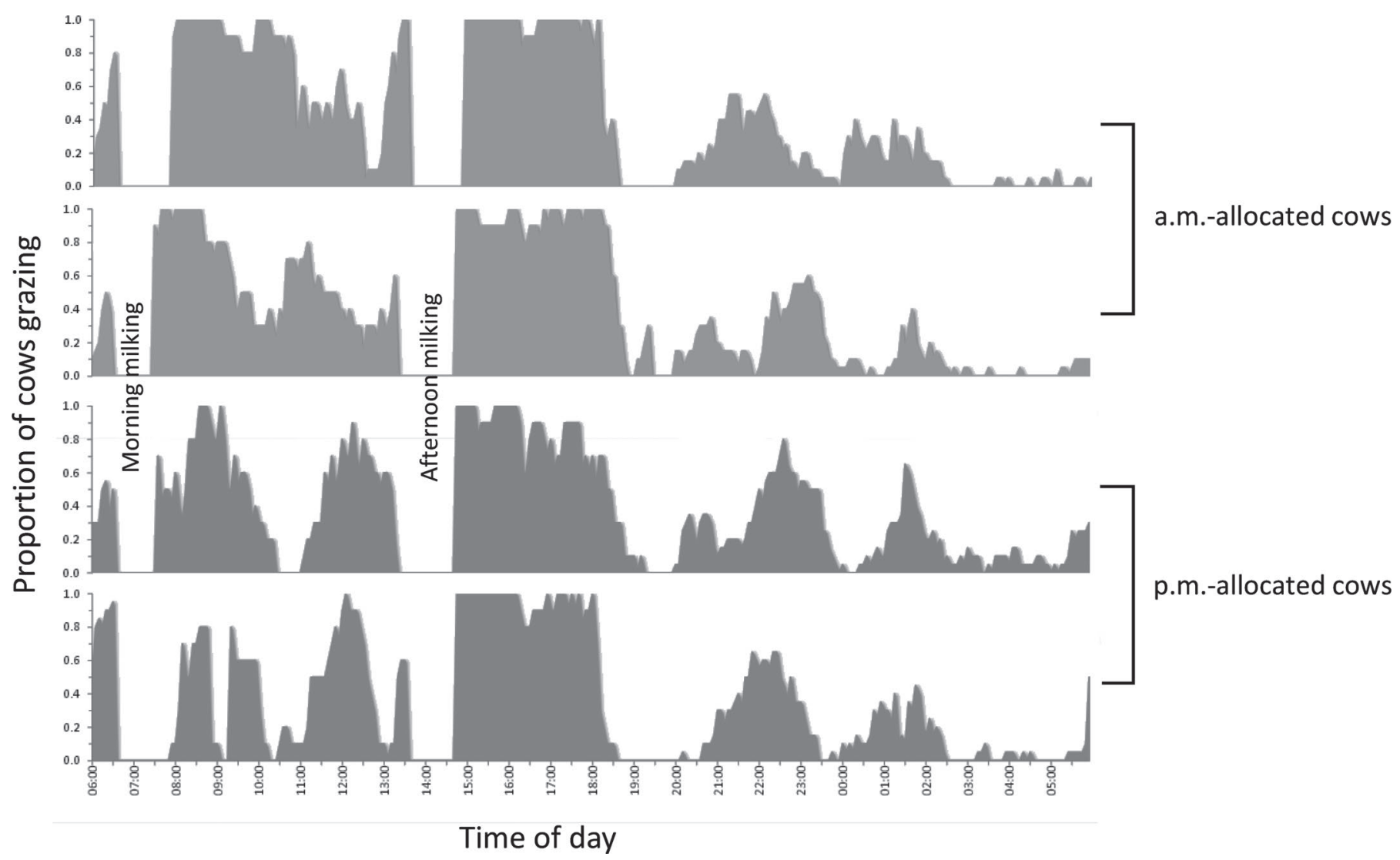

Figure 1. Proportion of cows grazing a new strip of pasture $(1.0=$ all cows grazing; $0.0=$ no cows grazing $)$ offered either in the morning (a.m.) or in the afternoon (p.m.). The top and third graphs correspond to period 1, the second and bottom graphs correspond to period 2 . 
before grazing and every $30 \mathrm{~min}$ up to $4 \mathrm{~h}$ after commencement of the main grazing events $(\mathrm{n}=8$ time points $\times 2$ herds $\times 2$ treatments $\times 2$ periods $=64$ herbage samples). Samples were hand-plucked from about 10 sites on each walking transect to mimic herbage grazed by the cows. Samples were immediately placed in ice, transported to the laboratory and stored frozen $\left(-20^{\circ} \mathrm{C}\right)$, and subsequently freeze-dried and ground to pass a 1-mm Wiley mill sieve. Chemical composition was obtained by near infrared reflectance spectroscopy (FeedTECH, Palmerston North, New Zealand). All herbage samples were analyzed for ash, WSC, NDF, $\mathrm{ADF}, \mathrm{CP}$, and lipid concentrations, along with $\mathrm{OM}$ digestibility and $\mathrm{ME}(\mathrm{MJ} / \mathrm{kg}$ of $\mathrm{DM})$ concentration (Corson et al., 1999). Also, subsamples collected during the first 60 min post allocation $(\mathrm{n}=2$ time points $\times 2$ herds $\times 2$ treatments $\times 2$ periods $=16)$ were analyzed for soluble $\mathrm{CP}$ (NPN + soluble protein), degradable protein, neutral-detergent insoluble protein and aciddetergent insoluble protein by wet chemistry (Dairy One Forage Lab Services, Ithaca, NY).

For herbage FA composition, freeze-dried pasture subsamples collected during the first 60 min post allocation $(\mathrm{n}=16)$ were extracted and methylated in a one-step incubation procedure with a mixture of toluene (Analar reagent), methanol and sulfuric acid (2.5\% $\mathrm{vol} / \mathrm{vol}$ sulfuric acid in methanol), according to Sukhija and Palmquist (1988). The samples were analyzed with a Shimadzu gas chromatograph (Shimadzu GC 2010, with a flame ionization detector; Shimadzu, Kyoto, Japan). The FAME were separated on a 100-m fused silica column (i.d. $0.25 \mathrm{~mm}$; film thickness $0.2 \mu \mathrm{m}$; Restek Rtx-2330; Restek Corporation, Bellefonte, PA). Injection port and detector temperatures were maintained at 240 and $265^{\circ} \mathrm{C}$, respectively, with hydrogen $(50 \mathrm{~cm} / \mathrm{s})$ used as the carrier gas. Nineteen FAME were identified via retention time and quantified relative to tri-C11 (triundecanoin) used as an internal standard, and their corresponding response was obtained from the concurrent analysis of an external standard (Supelco FAME Mix C4-C24, Sigma-Aldrich). Fatty acids in pasture samples are also expressed as grams per 100 $\mathrm{g}$ of total FA.

\section{Statistical Analysis}

Dependent variables (i.e., herbage chemical composition, estimates of herbage DMI, milk production and composition, grazing behavior, urinary $\mathrm{N}$ ) were analyzed using SAS software (version 9.3; SAS Institute Inc., Cary, NC). Herbage chemical composition, measures of herbage availability, and estimates of herbage DMI were analyzed using a mixed model procedure (PROC MIXED; SAS Institute Inc.). The model in- cluded the fixed effects of treatment, day of sampling, and their interaction, and the random effect of paddock. Day of sampling and interaction effects were deemed not significant and subsequently dropped from the model. Paddock was considered the experimental unit. The effects of time of day at which herbage sample collection occurred $(0730,1130,1530,1930 \mathrm{~h})$ were analyzed using a similar procedure; the model included the fixed effects of time of day, day of sampling, and their interaction, and the random effect of paddock. Similarly, day of sampling and interaction effects were deemed not significant and subsequently dropped from the model; mean comparisons were performed using the Tukey test.

Milk yield and milk composition along with urinary $\mathrm{N}$ concentrations were analyzed using a mixed model procedure with repeated measurements over time. The models included fixed (treatment) and random (cow within herd) effects. Grazing time was also analyzed using a mixed model procedure, whereas pasture disappearance data were analyzed using a nonlinear procedure (PROC NLIN; SAS Institute Inc.). The model of Ørskov and McDonald (1979) was used to analyze the pasture disappearance data for each herd, using the Marquardt method to obtain the parameter estimates $a, b$, and $c$, as outlined by Gregorini et al. (2009a). Comparison of parameters was performed using a mixed model procedure (PROC MIXED; SAS Institute Inc.) with herd as the experimental unit. Significance and trends were established at $P<0.05$ and $P<0.10$, respectively.

\section{RESULTS}

\section{Weather Conditions}

Compared with long-term weather data for the month of April (mean air temperature $11.8^{\circ} \mathrm{C}$, mean precipitation $56.8 \mathrm{~mm}$, mean relative humidity $79.9 \%$; 2001-2010), mean air temperature (at a 2-m height) was similar $\left(12.0^{\circ} \mathrm{C}\right)$, precipitation was lesser $(33.4 \mathrm{~mm})$, and relative humidity was slightly greater $(82.5 \%)$ (The National Climate Database, National Institute of Water and Atmospheric Research, Wellington, New Zealand). The mean amount of hours of sunlight and daily solar radiation during the experimental period were similar to those reported for a longer term for the month of April $\left(5.1 \mathrm{~h} / \mathrm{d}\right.$ and $11.0 \mathrm{MJ} / \mathrm{m}^{2}$ vs. $5.2 \mathrm{~h} / \mathrm{d}$ and 11.4 $\mathrm{MJ} / \mathrm{m}^{2}$, respectively).

\section{Herbage Chemical Composition}

Herbage composition differed among treatments; p.m. herbage had greater DM (22.7 vs. $19.9 \%$; $P=$ $0.008), \mathrm{OM}(89.5$ vs. $88.9 \% ; P<0.001)$, and $\mathrm{WSC}$ 
(10.9 vs. $7.6 \% ; P<0.001)$ concentrations and lesser $\mathrm{CP}$ $(20.5$ vs. $22.2 \% ; P<0.001)$ and NDF (48.8 vs. $50.4 \%$; $P=0.02)$ concentrations compared with a.m. herbage (Table 1). To a lesser extent, lipid concentration tended to be reduced in p.m. herbage (2.8 vs. $3.1 \% ; P=0.10$ ), whereas $\mathrm{OM}$ digestibility and $\mathrm{ME}$ concentrations were similar among treatments $(78.0 \pm 0.57 \%$ and $11.4 \pm$ $0.08 \mathrm{MJ} \mathrm{ME} / \mathrm{kg} \mathrm{DM}$, respectively). Except for soluble protein, which was greater $(P=0.02)$ for a.m. herbage, all other $\mathrm{CP}$ fractions were similar among treatments (Table 1).

$\alpha$-Linolenic acid (ALA; C18:3 cis-9,12,15) and PUFA were greater $(P<0.05)$ in a.m. herbage, whereas lauric acid (C12:0), palmitoleic acid (C16:1), stearic acid (C18:0), oleic acid (C18:1 cis-9), arachidic acid (C20:0), and MUFA were greater $(P<0.05)$ in p.m. herbage (Table 1$)$. A trend $(P<0.10)$ was also observed for greater myristic acid (C14:0), palmitic acid (PA; C16:0), and total saturated FA in p.m. herbage.
Herbage WSC concentrations increased throughout the day, attaining a maximum value at $1530 \mathrm{~h}(10.3 \%$; commencement of the main p.m. grazing event), whereas other plant constituents varied numerically rather than statistically (Table 2). It is important to note, however, that the mean values of the diurnal pattern in chemical composition presented in Table 2 were derived from only 4 samples collected at each time point (2 herds $\times 2$ periods), whereas the treatment comparison (Table 1) was derived from 32 herbage samples (2 herds $\times 2$ periods $\times 8$ time points) analyzed per treatment.

\section{Herbage Quantity and Intake, Milk Production, and Milk Composition}

Herbage mass offered (i.e., pregrazing $\mathrm{HM}$ ) and refused (i.e., postgrazing $\mathrm{HM}$ ) during the entire experiment did not differ among treatments; mean $( \pm \mathrm{SE})$ pre- and postgrazing HM were $2,872 \pm 147 \mathrm{~kg}$ of DM/

Table 1. Chemical composition (\% of DM unless noted otherwise) of herbage allotted to cows either in the morning (a.m.) or in the afternoon (p.m.) ( $\mathrm{n}=64$ herbage samples, unless specified otherwise)

\begin{tabular}{|c|c|c|c|c|}
\hline \multirow[b]{2}{*}{ Chemical composition } & \multicolumn{2}{|c|}{ Treatment } & \multirow[b]{2}{*}{$\mathrm{SE}$} & \multirow[b]{2}{*}{$P \leq$} \\
\hline & a.m. & p.m. & & \\
\hline $\mathrm{DM}, \%$ & 19.9 & 22.7 & 0.70 & 0.008 \\
\hline $\mathrm{OM}$ & 88.9 & 89.5 & 0.09 & $<0.001$ \\
\hline Water-soluble carbohydrates & 7.6 & 10.9 & 0.45 & $<0.001$ \\
\hline Starch & 0.46 & 0.45 & 0.27 & 0.92 \\
\hline NDF & 50.4 & 48.8 & 0.45 & 0.02 \\
\hline $\mathrm{ADF}$ & 25.7 & 25.8 & 0.26 & 0.93 \\
\hline Lipid & 3.1 & 2.8 & 0.16 & 0.10 \\
\hline OM disappearance, $\%$ of $\mathrm{OM}$ & 78.1 & 77.9 & 0.57 & 0.85 \\
\hline $\mathrm{ME}, \mathrm{MJ} / \mathrm{kg}$ of $\mathrm{DM}$ & 11.4 & 11.4 & 0.08 & 0.90 \\
\hline $\mathrm{CP}$ & 22.2 & 20.5 & 0.25 & $<0.001$ \\
\hline \multicolumn{5}{|c|}{ Protein fractions, $\%$ of $\mathrm{CP}(\mathrm{n}=16$ samples $)$} \\
\hline Soluble protein & 35.4 & 30.4 & 2.04 & 0.02 \\
\hline Degradable protein & 73.6 & 74.4 & 2.16 & 0.50 \\
\hline $\mathrm{NDICP}^{1}$ & 6.3 & 5.9 & 0.88 & 0.33 \\
\hline $\mathrm{ADICP}^{2}$ & 2.6 & 2.1 & 0.76 & 0.21 \\
\hline FA $(\mathrm{n}=16$ samples $)$ & 2.2 & 1.8 & 0.10 & 0.03 \\
\hline \multicolumn{5}{|l|}{ Individual FA, $\mathrm{g} / 100 \mathrm{~g}$ of $\mathrm{FA}$} \\
\hline C12:0 & 2.39 & 2.94 & 0.12 & 0.006 \\
\hline C14:0 & 0.88 & 1.08 & 0.07 & 0.06 \\
\hline C16:0 & 25.25 & 29.43 & 1.65 & 0.09 \\
\hline C16:1 & 0.50 & 0.63 & 0.04 & 0.04 \\
\hline C18:0 & 2.79 & 3.31 & 0.17 & 0.05 \\
\hline C18:1 cis-9 & 2.72 & 3.50 & 0.19 & 0.01 \\
\hline $\mathrm{C} 18: 1$ cis-11 & 0.49 & 0.51 & 0.03 & 0.62 \\
\hline C18:2 cis-9, cis-12 & 10.54 & 9.73 & 0.57 & 0.34 \\
\hline C18:3 cis-9,cis-12,cis-15 & 44.96 & 38.25 & 2.22 & 0.04 \\
\hline $\mathrm{C} 20: 0$ & 0.75 & 0.94 & 0.05 & 0.02 \\
\hline $\mathrm{C} 22: 0$ & 2.66 & 2.65 & 0.28 & 0.99 \\
\hline $\mathrm{C} 24: 0$ & 2.41 & 2.60 & 0.24 & 0.59 \\
\hline SFA, $\%$ of total FA & 38.6 & 44.6 & 2.40 & 0.06 \\
\hline MUFA, ${ }^{3} \%$ of total FA & 4.3 & 5.5 & 0.23 & 0.002 \\
\hline PUFA, ${ }^{4} \%$ of total FA & 57.1 & 49.9 & 2.52 & 0.04 \\
\hline
\end{tabular}


Table 2. Diurnal pattern of the main plant constituents of ryegrass (Lolium perenne)-based herbage during daylight hours

\begin{tabular}{lccccccc}
\hline & \multicolumn{7}{c}{ Chemical composition, \% of DM $^{1}$} \\
\cline { 2 - 8 } Time of day & OM & \multirow{2}{*}{ NFC $^{2}$} & WSC & NDF & ADF & CP & Lipid \\
\hline $0730 \mathrm{~h}$ & 88.6 & 12.5 & $6.0^{\mathrm{a}}$ & 51.5 & 26.5 & 21.5 & 3.0 \\
$1130 \mathrm{~h}$ & 88.8 & 13.4 & $8.2^{\mathrm{ab}}$ & 50.9 & 26.3 & 21.6 & 3.0 \\
$1530 \mathrm{~h}$ & 88.9 & 14.8 & $10.3^{\mathrm{b}}$ & 48.9 & 25.5 & 21.8 & 3.4 \\
$1930 \mathrm{~h}$ & 89.3 & 15.2 & $10.1^{\mathrm{b}}$ & 51.3 & 27.2 & 19.8 & 2.9 \\
SE & 0.19 & 1.22 & 0.95 & 1.50 & 0.79 & 0.69 & 0.12 \\
\hline
\end{tabular}

${ }^{\mathrm{a}, \mathrm{b}}$ Mean values in the same column with different superscripts differ $(P<0.05)$.

${ }^{1} \mathrm{n}=4$ herbage samples per time point.

${ }^{2} \mathrm{NFC}=100-($ ash $+\mathrm{CP}+\mathrm{NDF}+$ lipid $)$.

${ }^{3}$ Water-soluble carbohydrates.

ha $(P=0.39)$ and $1,831 \pm 63 \mathrm{~kg} \mathrm{DM} / \mathrm{ha}(P=0.46)$, respectively (Table 3 ). Similarly, area offered daily to cows did not differ among treatments $(0.393 \pm 0.1$ ha; $P=0.26$ ). Consequently, estimates of herbage DMI from pre- and postgrazing HM did not differ among treatments $(12.8 \pm 0.7 \mathrm{~kg} \mathrm{DM} / \mathrm{d})$ (Table 3). Daily milk yields, percent milk fat, and percent milk CP were similar among treatments, whereas milk fat yields (684 vs. $627 \mathrm{~g} /$ cow; $P=0.05$ ), milk CP yields (545 vs. $505 \mathrm{~g} /$ cow; $P=0.10)$, and MSY (1,228 vs. $1,132 \mathrm{~g} \mathrm{MSY/cow;}$ $P=0.08)$ tended to be greater for cows on p.m. herbage. Milk urea $\mathrm{N}$ concentrations $(15.2 \pm 0.3 \mathrm{mg} / \mathrm{dL})$ and SCS $(3.6 \pm 0.1)$ did not differ among treatments.

Four of the 49 milk FA analyzed differed in their relative contribution to total $\mathrm{FA}(\mathrm{g} / 100 \mathrm{~g}$ total FA; $P$ $<0.05$ ) between cows offered an a.m. or a p.m. allocation of a fresh strip of pasture (Table 4). Oleic acid
(C18:1 cis-9) and cis-vaccenic acid (cis-VA; C18:1 cis-11) were greater in milk from cows on p.m. herbage, whereas the branched-chain FA iso-hexadecanoic acid (iso-C16:0) and rumenic acid (RA; CLA isomer C18:2 cis-9, trans-11) were greater in milk from cows on a.m. herbage. Total PUFA in milk were greater $(P$ $<0.05)$ from cows on a.m. herbage (7.61 vs. $7.22 \mathrm{~g} / 100$ g FA; $P=0.01)$, whereas total saturated FA, odd- and branched-chain fatty acids (OBCFA; both total and those of microbial origin), and MUFA were similar among dietary treatments.

\section{Nitrogen Partition}

Estimates of $\mathrm{N}$ intake (calculated from herbage DMI and $\mathrm{N}$ concentration in herbage) tended to be greater for cows on a.m. herbage $(P=0.09)$, whereas $\mathrm{N}$ output

Table 3. Herbage mass (HM) offered and refused, estimates of intake, milk production and milk composition from cows offered a new strip of pasture either in the morning (a.m., allotted at $0730 \mathrm{~h}$ ) or in the afternoon (p.m., allotted at $1530 \mathrm{~h}$ )

\begin{tabular}{lcccc}
\hline & \multicolumn{2}{c}{ Treatment } & & \\
\cline { 2 - 3 } Variable $^{1}$ & $\mathrm{n} . \mathrm{m}$. & $\mathrm{p} . \mathrm{m}$. & SE & $P \leq$ \\
\hline Pregrazing HM, kg of DM/ha & 2,856 & 2,889 & 147 & 0.39 \\
Postgrazing HM, kg of DM/ha & 1,818 & 1,844 & 63 & 0.46 \\
Grazing area, ha/d & 0.40 & 0.39 & 0.11 & 0.26 \\
Intake, ${ }^{2} \mathrm{~kg} / \mathrm{d}$ & 12.7 & 12.9 & 0.7 & 0.75 \\
Milk, kg/d & 12.2 & 13.1 & 0.3 & 0.16 \\
Milk fat, \% & 5.15 & 5.27 & 0.06 & 0.16 \\
Milk fat, g/d & 627 & 684 & 6 & 0.05 \\
Milk protein, \% & 4.15 & 4.19 & 0.02 & 0.20 \\
Milk protein, g/d & 505 & 545 & 9 & 0.10 \\
Milk solids, ${ }^{3}$ g/d & 1,132 & 1,228 & 17 & 0.08 \\
MUN, mg/dL & 15.0 & 15.3 & 0.3 & 0.51 \\
SCS $^{4}$ & 3.57 & 3.64 & 0.08 & 0.52 \\
\hline
\end{tabular}

${ }^{1}$ Estimates of the first 4 variables (pre- and postgrazing HM, grazing area, and DMI) were obtained using paddock as the experimental unit, whereas the remaining variables (milk and milk composition) were obtained using animal as the experimental unit (see text for more detail).

${ }^{2} \mathrm{DM}$ basis. Estimates obtained by difference between pre- and postgrazing HM.

${ }^{3}$ Milk solids $=$ milk fat + milk protein.

${ }^{4} \mathrm{SCS}=\left\{\left[\log _{10}(\mathrm{SCC} / 1000)-2\right] / \log _{10}(2)\right\}+3$. 
in milk tended to be greater for cows on p.m. herbage $(P=0.10)$ (Table 5). Estimates of urinary $\mathrm{N}$ excretion, however, did not differ among treatments $(220 \pm 6.9$ $\mathrm{g} / \mathrm{d}$ and $194 \pm 6.2 \mathrm{~g} / \mathrm{d}$ obtained from Equations [3] and [4], respectively). Urinary $\mathrm{N}$ concentration (g/L) was greater for cows on a.m. herbage (5.85 vs. 5.36 $\mathrm{g} / \mathrm{L}, P=0.04$; Table 5$)$ and was higher in samples collected during the morning $(6.18$ vs. $5.04 \mathrm{~g} / \mathrm{L}, \mathrm{SE}=$

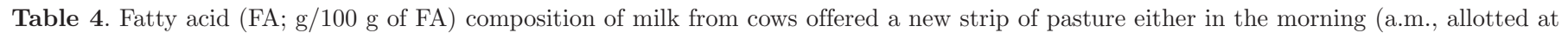
$0730 \mathrm{~h}$ ) or in the afternoon (p.m., allotted at $1530 \mathrm{~h}$ ) and time of milking (afternoon or morning)

\begin{tabular}{|c|c|c|c|c|c|c|c|c|c|}
\hline \multirow{2}{*}{$\begin{array}{l}\text { FA, } \\
\mathrm{g} / 100 \mathrm{~g} \text { of } \mathrm{FA}\end{array}$} & \multicolumn{3}{|c|}{ Time of allocation (A) } & \multicolumn{3}{|c|}{ Time of milking $(\mathrm{M})^{1}$} & \multicolumn{3}{|c|}{$P \leq$} \\
\hline & a.m. & p.m. & $\mathrm{SED}^{2}$ & Afternoon & Morning & SED & $\mathrm{A}$ & M & $\mathrm{A} \times \mathrm{M}$ \\
\hline \multicolumn{10}{|l|}{ Even-chain SFA } \\
\hline $\mathrm{C} 10: 0$ & 2.43 & 2.35 & 0.135 & 2.33 & 2.46 & 0.058 & 0.64 & 0.03 & 0.10 \\
\hline C12:0 & 2.96 & 2.87 & 0.091 & 2.88 & 2.95 & 0.074 & 0.66 & 0.35 & 0.13 \\
\hline C14:0 & 10.77 & 10.59 & 0.278 & 10.70 & 10.67 & 0.151 & 0.58 & 0.83 & 0.009 \\
\hline C16:0 & 19.96 & 19.31 & 0.569 & 19.57 & 19.71 & 0.282 & 0.38 & 0.59 & 0.23 \\
\hline C18:0 & 8.76 & 9.08 & 0.244 & 9.22 & 8.62 & 0.244 & 0.18 & 0.02 & 0.55 \\
\hline C20:0 & 0.11 & 0.11 & 0.005 & 0.12 & 0.10 & 0.003 & 0.91 & $<0.001$ & 0.24 \\
\hline $\mathrm{C} 22: 0$ & 0.045 & 0.044 & 0.0018 & 0.050 & 0.039 & 0.0017 & 0.43 & $<0.001$ & 0.42 \\
\hline $\mathrm{C} 24: 0$ & 0.027 & 0.026 & 0.0011 & 0.030 & 0.023 & 0.0011 & 0.11 & $<0.001$ & 0.45 \\
\hline \multicolumn{10}{|l|}{ Odd-chain SFA } \\
\hline $\mathrm{C} 11: 0$ & 0.032 & 0.027 & 0.0024 & 0.029 & 0.030 & 0.0015 & 0.20 & 0.40 & 0.93 \\
\hline $\mathrm{C} 13: 0$ & 0.068 & 0.062 & 0.0030 & 0.066 & 0.064 & 0.0017 & 0.19 & 0.23 & 0.88 \\
\hline C15:0 & 2.58 & 2.48 & 0.031 & 2.59 & 2.48 & 0.026 & 0.08 & $<0.001$ & 0.36 \\
\hline C17:0 & 1.14 & 1.12 & 0.026 & 1.16 & 1.10 & 0.016 & 0.45 & $<0.001$ & 0.30 \\
\hline $\mathrm{C} 21: 0$ & 0.045 & 0.045 & 0.0019 & 0.051 & 0.040 & 0.0019 & 0.70 & $<0.001$ & 0.37 \\
\hline $\mathrm{C} 23: 0$ & 0.039 & 0.038 & 0.0018 & 0.043 & 0.033 & 0.0018 & 0.52 & $<0.001$ & 0.22 \\
\hline \multicolumn{10}{|l|}{ Branched-chain FA } \\
\hline C14:0 iso & 0.099 & 0.096 & 0.0016 & 0.102 & 0.093 & 0.0013 & 0.25 & $<0.001$ & 0.24 \\
\hline $\mathrm{C} 15: 0$ iso & 0.14 & 0.14 & 0.003 & 0.15 & 0.12 & 0.003 & 0.93 & 0.001 & $<0.001$ \\
\hline $\mathrm{C} 15: 0$ anteiso & 0.82 & 0.78 & 0.027 & 0.82 & 0.78 & 0.013 & 0.30 & $<0.001$ & 0.29 \\
\hline $\mathrm{C} 16: 0$ iso & 0.70 & 0.68 & 0.008 & 0.72 & 0.66 & 0.008 & 0.01 & $<0.001$ & 0.001 \\
\hline $\mathrm{C} 17: 0$ iso & 0.73 & 0.72 & 0.009 & 0.76 & 0.70 & 0.009 & 0.37 & $<0.001$ & 0.26 \\
\hline C17:0 anteiso & 0.64 & 0.61 & 0.015 & 0.64 & 0.607 & 0.011 & 0.23 & 0.001 & 0.49 \\
\hline C18:0 iso & 0.030 & 0.028 & 0.0015 & 0.031 & 0.027 & 0.0006 & 0.29 & $<0.001$ & 0.02 \\
\hline \multicolumn{10}{|l|}{ MUFA } \\
\hline C14:1 & 1.21 & 1.12 & 0.041 & 1.18 & 1.16 & 0.034 & 0.16 & 0.49 & 0.06 \\
\hline $\mathrm{C} 16: 1$ cis-9 & 4.26 & 4.21 & 0.117 & 4.26 & 4.21 & 0.117 & 0.66 & 0.68 & 0.37 \\
\hline C16:1 trans -9 & 0.654 & 0.642 & 0.0191 & 0.667 & 0.629 & 0.0142 & 0.60 & 0.01 & 0.57 \\
\hline $\mathrm{C} 17: 1$ cis -9 & 0.74 & 0.90 & 0.069 & 0.69 & 0.95 & 0.022 & 0.14 & $<0.001$ & $<0.001$ \\
\hline $\mathrm{C} 18: 1$ cis-9 & 16.69 & 17.34 & 0.205 & 17.11 & 16.92 & 0.205 & 0.002 & 0.38 & 0.39 \\
\hline C18:1 trans -9 & 0.61 & 0.62 & 0.017 & 0.65 & 0.58 & 0.010 & 0.77 & $<0.001$ & 0.38 \\
\hline $\mathrm{C} 18: 1$ cis-11 & 2.15 & 2.26 & 0.027 & 2.29 & 2.11 & 0.028 & $<0.001$ & $<0.001$ & 0.35 \\
\hline C18:1 trans-11 & 7.14 & 6.67 & 0.403 & 7.30 & 6.51 & 0.212 & 0.35 & $<0.001$ & 0.49 \\
\hline C19:1 & 0.35 & 0.36 & 0.005 & 0.37 & 0.34 & 0.005 & 0.11 & $<0.001$ & 0.21 \\
\hline \multicolumn{10}{|l|}{ PUFA } \\
\hline $\mathrm{C} 18: 2$ cis- 9, cis -12 & 1.51 & 1.54 & 0.060 & 1.59 & 1.46 & 0.022 & 0.67 & $<0.001$ & 0.76 \\
\hline $\mathrm{C} 18: 2$ cis-9, trans-11 & 3.30 & 2.87 & 0.131 & 3.30 & 2.88 & 0.130 & 0.001 & 0.001 & 0.74 \\
\hline $\mathrm{C} 18: 2$ trans -10 , cis -12 & 0.53 & 0.49 & 0.026 & 0.57 & 0.45 & 0.016 & 0.24 & $<0.001$ & 0.87 \\
\hline $\mathrm{C} 18: 3$ & 1.84 & 1.94 & 0.097 & 1.98 & 1.80 & 0.037 & 0.45 & $<0.001$ & 0.03 \\
\hline $\mathrm{C} 20: 2$ & 0.013 & 0.012 & 0.0005 & 0.014 & 0.011 & 0.0004 & 0.35 & $<0.001$ & 0.22 \\
\hline C20:3n-3 & 0.071 & 0.069 & 0.0060 & 0.076 & 0.064 & 0.0017 & 0.81 & $<0.001$ & 0.83 \\
\hline C20:3n-6 & 0.023 & 0.023 & 0.0008 & 0.026 & 0.021 & 0.0007 & 0.76 & $<0.001$ & 0.31 \\
\hline $\mathrm{C} 20: 4 \mathrm{n}-6$ & 0.11 & 0.10 & 0.009 & 0.12 & 0.09 & 0.003 & 0.22 & $<0.001$ & 0.97 \\
\hline C20:5n-3 & 0.18 & 0.17 & 0.012 & 0.19 & 0.16 & 0.004 & 0.46 & $<0.001$ & 0.35 \\
\hline $\mathrm{C} 22: 6 \mathrm{n}-3$ & 0.022 & 0.020 & 0.0019 & 0.023 & 0.018 & 0.0009 & 0.36 & $<0.001$ & 0.02 \\
\hline Total SFA & 58.0 & 58.1 & 0.46 & 57.1 & 59.1 & 0.45 & 0.82 & $<0.001$ & 0.72 \\
\hline Total OBCFA ${ }^{3}$ & 7.89 & 7.82 & 0.072 & 7.93 & 7.78 & 0.072 & 0.29 & 0.05 & 0.51 \\
\hline OBCFA microbial $^{4}$ & 7.58 & 7.53 & 0.072 & 7.62 & 7.49 & 0.072 & 0.51 & 0.07 & 0.57 \\
\hline Total MUFA & 34.4 & 34.7 & 0.35 & 35.0 & 33.9 & 0.34 & 0.30 & 0.001 & 0.72 \\
\hline Total PUFA & 7.61 & 7.22 & 0.148 & 7.88 & 6.96 & 0.148 & 0.01 & $<0.001$ & 0.79 \\
\hline Total FA, mg/mL & 33.4 & 39.2 & 3.51 & 39.5 & 33.0 & 1.43 & 0.24 & $<0.001$ & 0.36 \\
\hline
\end{tabular}

${ }^{1}$ Afternoon (starting at $\sim 1430 \mathrm{~h}$ ) or morning (starting at $\sim 0630 \mathrm{~h}$ ) milking.

${ }^{2} \mathrm{SED}=$ standard error of the difference.

${ }^{3} \mathrm{OBCFA}=$ odd- and branched-chain fatty acids.

${ }^{4}$ OBCFA of microbial origin (sum of iso C14:0, C15:0, iso C15:0, anteiso C15:0, iso C16:0, C17:0, iso C17:0, anteiso C17:0, and C17:1 cis-9) (Vlaeminck et al., 2006). 
Table 5. Nitrogen $(\mathrm{N})$ intake, $\mathrm{N}$ in milk, and $\mathrm{N}$ in urine from cows offered a new strip of pasture either in the morning (a.m., allotted at $\sim 0730 \mathrm{~h}$ ) or in the afternoon (p.m., allotted at $\sim 1530 \mathrm{~h}$ )

\begin{tabular}{|c|c|c|c|c|}
\hline \multirow[b]{2}{*}{ Variable } & \multicolumn{2}{|c|}{ Treatment } & \multirow[b]{2}{*}{$\mathrm{SE}$} & \multirow[b]{2}{*}{$P \leq$} \\
\hline & a.m. & p.m. & & \\
\hline$\overline{N \text { intake }^{1}(\mathrm{NI}), \mathrm{g} / \mathrm{d}}$ & 475 & 426 & 26.8 & 0.09 \\
\hline $\mathrm{N}$ in milk, $\mathrm{g} / \mathrm{d}$ & 79.2 & 85.4 & 1.4 & 0.10 \\
\hline $\mathrm{N}$ in milk (proportion of $\mathrm{NI}$ ) & 0.17 & 0.20 & & \\
\hline Concentration of $\mathrm{N}$ in urine, $\mathrm{g} / \mathrm{L}$ & 5.85 & 5.36 & 0.24 & 0.04 \\
\hline $\mathrm{N}$ in urine, ${ }^{2} \mathrm{~g} / \mathrm{d}$ & 220.0 & 219.2 & 6.9 & 0.93 \\
\hline $\mathrm{N}$ in urine (proportion of $\mathrm{NI}$ ) & 0.46 & 0.51 & & \\
\hline $\mathrm{N}$ in urine,${ }^{3} \mathrm{~g} / \mathrm{d}$ & 192.1 & 195.2 & 6.2 & 0.60 \\
\hline $\mathrm{N}$ in urine (proportion of $\mathrm{NI}$ ) & 0.40 & 0.46 & & \\
\hline Creatinine in urine, $\mathrm{mg} / \mathrm{L}$ & 275 & 268 & 5 & 0.40 \\
\hline
\end{tabular}

$0.22 \mathrm{~g} / \mathrm{L} ; P<0.01)$ compared with samples collected in the afternoon (data not shown).

\section{Grazing Behavior}

Total time spent grazing was similar among treatments $(510 \pm 11.6 \mathrm{~min} ; P=0.21$; Table 6; Figure 1). Time spent grazing during the first $4 \mathrm{~h}$ after a.m. milking was greater for cows on a.m. than for cows on p.m. herbage (196 vs. $110 \mathrm{~min} ; P<0.001$ ), whereas time spent grazing during the $4 \mathrm{~h}$ after p.m. milking was similar among treatments. Time spent grazing (cows grazing as a proportion of all cows in the herd) is represented in Figure 1. During the grazing behavior observation periods, initial HM available ( $\mathrm{kg}$ of $\mathrm{DM} /$ ha), potential HM disappearance ( $\mathrm{kg}$ of $\mathrm{DM} / \mathrm{ha}$ ), and instantaneous HM disappearance rates ( $\mathrm{kg}$ of DM/ha per hour) did not differ among treatments. Fractional disappearance rates, however, were greater for cows on p.m. herbage (0.74 vs. 0.56 per hour; $P=0.04$; Table $6)$.

\section{DISCUSSION}

Although strip grazing is a commonly adopted grazing method in pastoral dairying, the role of timing of herbage allocation on milk FA profiles has only received limited attention. Despite similar partitioning of $\mathrm{N}$ toward urine, allocating a fresh strip later in the day resulted in moderate increases in $\mathrm{N}$ captured in milk and milk solids yields in late-lactation dairy cows. Conversely, a greater concentration of beneficial FA in a.m. herbage resulted in a greater concentration of RA and PUFA in milk from cows on a.m. herbage compared with cows on p.m. herbage.

\section{Time of Feed Allocation and Herbage Chemical Composition}

In our experiment, DM concentration increased by $14 \%$ by offering p.m. versus a.m. forage. Similar differences have been reported for vegetative ryegrass (up to $25 \%$ ) sampled at 1000 and $1600 \mathrm{~h}$ (Pulido et al., $2015)$ and for vegetative wheat (20\%) sampled at either 0800 or 1900 h (Gregorini et al., 2008). Differences in diurnal OM concentration, however, were smaller than those reported by Gregorini et al. (2008) for similar time points ( $0.8 \%$ vs. $6 \%$, respectively); however, initial $\mathrm{OM}$ values in the present study were greater than those reported in that study (88.6 vs. $83.0 \%$ ).

Greater concentrations of WSC are a direct consequence of increased accumulation of photosynthates in leaves as the day progresses; WSC concentration increased by $43 \%$ in p.m. herbage compared with a.m. herbage. Similar differences $(46 \%)$ were reported for ryegrass in autumn by Pulido et al. (2015). Although not statistically significant, NDF concentration throughout the day was greatest at $0730 \mathrm{~h}$, reaching the lowest value at $1530 \mathrm{~h}$ and increasing again at 1930 $\mathrm{h}$, similar to the initial NDF concentration measured, a diurnal pattern similar to vegetative wheat (Gregorini et al., 2008) and alfalfa (Burns et al., 2005). An inverse relationship occurred between NDF and both WSC and neutral detergent solubles (100 - NDF), and this pattern was presumably attributed to greater respiration and metabolic activity of plants during the late evening hours. The variations in chemical composition reported in the present experiment are also in agreement with those reported by Delagarde et al. (2000) for samples of perennial ryegrass collected at 0800 and $1900 \mathrm{~h}$.

Increases in WSC concentration at the expense of CP have been attributed to decreased amount of carbon 
chains partitioned toward protein synthesis and corresponding decreased energy required in nitrate reduction before protein synthesis (Peyraud and Astigarraga, 1998). Genetic improvements in WSC concentration (i.e., WSC-enhanced cultivars or high-sugar ryegrasses) often, but not always, occur at the expense of structural carbohydrates (i.e., NDF), suggesting an improved carbon partition between carbohydrate fractions for WSCenhanced cultivars (Miller et al., 2001). Greater concentrations of WSC from a high-sugar perennial ryegrass grown in New Zealand were offset largely by reductions in protein, and to a lesser extent, by reductions in NDF concentration (Cosgrove et al., 2009). Provided these relationships are sustained, concerted efforts toward increasing WSC could lead to further nutritional and environmental benefits from reducing both $\mathrm{CP}$ and NDF concentrations from incremental WSC. Overall, results reported herein sustain this premise; the herbage allocated to cows after the afternoon milking was of greater nutritive value to potentially support greater milk production than that allocated after the morning milking.

In addition to perennial ryegrass, exploiting diurnal variation in WSC concentrations as a means of nutritive value enhancement has been reported for other forages such as Italian ryegrass (Lolium multiflorum Lam.) (Trevaskis et al., 2004), phalaris (Phalaris aquatica L.) (Ciavarella et al., 2000), tall fescue [Lolium arundinaceum (Schreb.) Darbysh.] (Fisher et al., 1999), cocksfoot (Dactylis glomerata L.) (Griggs et al., 2005), wheat (Triticum aestivum L.) (Gregorini et al., 2008), and alfalfa (Medicago sativa L.) (Brito et al., 2008). The photosynthetic processes (and associated sampling time during the main grazing events) had a considerable effect on various plant chemical components. These changes particularly occur in the upper layers of the sward, associated with processes of intense photosynthesis and gas exchange (Delagarde et al., 2000).

Ruminants offered fresh temperate forages have access to diets rich in PUFA, particularly ALA. A greater concentration of total FA, ALA, and PUFA in a.m. herbage is consistent with values reported by Doreau et al. (2007). Perennial ryegrasses manipulated for divergent soluble carbohydrate $(\mathbf{S C}): \mathrm{N}$ ratios $(+\mathrm{SC} /-\mathrm{N}$ vs. $-\mathrm{SC} /+\mathrm{N})$ offered as sole diets showed that the $-\mathrm{SC} /+\mathrm{N}$ ryegrass contained more $\mathrm{FA}(2.5$ vs. $1.8 \%$ of DM), a greater proportion of ALA (66 vs. $61 \%$ of total FA), and a greater proportion of PUFA (78 vs. $74 \%$ of total FA), often at the expense of saturated FA of 14 to $24 \mathrm{C}$ (Doreau et al., 2007). The greater concentrations of $\mathrm{FA}$ and $\mathrm{ALA}$ in $-\mathrm{SC} /+\mathrm{N}$ ryegrass were attributed to the association between FA and $\mathrm{N}$ in chloroplasts (Doreau et al., 2007), confirming the positive and overall linear relationship between ALA and $\mathrm{N}$ concentration in herbage (Elgersma, 2015), also seen in our study. The relationship between FA and

Table 6. Time spent grazing (min) and dynamics of herbage mass (HM) disappearance during the first $4 \mathrm{~h}$ of the main grazing event of cows offered a new strip of pasture either in the morning (a.m., allotted at $\sim 0730 \mathrm{~h}$ ) or in the afternoon (p.m., allotted at $\sim 1530$ h)

\begin{tabular}{|c|c|c|c|c|}
\hline \multirow[b]{2}{*}{ Variable } & \multicolumn{2}{|c|}{ Treatment } & \multirow[b]{2}{*}{$\mathrm{SE}$} & \multirow[b]{2}{*}{$P \leq$} \\
\hline & a.m. & p.m. & & \\
\hline \multicolumn{5}{|c|}{ Grazing time, $\min / \mathrm{d}$} \\
\hline Total & 525 & 495 & 11.6 & 0.21 \\
\hline \multicolumn{5}{|l|}{ First $4 \mathrm{~h}$} \\
\hline Post-a.m. ${ }^{1}$ & 196 & 110 & 9.9 & $<0.001$ \\
\hline Post-p.m. ${ }^{2}$ & 189 & 194 & 8.0 & 0.67 \\
\hline \multicolumn{5}{|l|}{ Parameter $^{3}$} \\
\hline$a$ & 3.352 & 3,256 & 84.6 & 0.43 \\
\hline$b$ & 1,069 & 970 & 59.2 & 0.24 \\
\hline$c$ & 0.56 & 0.74 & 0.08 & 0.04 \\
\hline \multicolumn{5}{|c|}{ HM disappearance rate ${ }^{4}$} \\
\hline $0 \min$ & 589 & 694 & 69.1 & 0.33 \\
\hline $60 \mathrm{~min}$ & 324 & 333 & 26.6 & 0.83 \\
\hline $120 \min$ & 184 & 163 & 20.5 & 0.50 \\
\hline $180 \mathrm{~min}$ & 108 & 82 & 17.7 & 0.33 \\
\hline $240 \mathrm{~min}$ & 65 & 42 & 14.3 & 0.29 \\
\hline
\end{tabular}

${ }^{1}$ After morning milking.

${ }^{2}$ After afternoon milking.

${ }^{3} \mathrm{HM}$ disappearance parameters were obtained by fitting HM data (y) from each herd into the equation $y=$ $a-b \times[1-\exp (-c \times$ time $)]$ (Ørskov and McDonald, 1979), where $a=$ pregrazing, available HM, $\mathrm{kg}$ of DM/ ha; $b=$ potential HM disappearance, $\mathrm{kg}$ of $\mathrm{DM} / \mathrm{ha} ; c=$ fractional disappearance rate of HM, per hour.

${ }^{4} \mathrm{HM}$ instantaneous disappearance rates ( $\mathrm{kg}$ of DM/ha per hour), estimated at 0,60,120, 180, and $240 \mathrm{~min}$ after commencement of the main grazing events. Calculated from the first derivative of the model above; instantaneous disappearance $y=-b \times c \times \exp (-c \times$ time) (Gregorini et al., 2009a). 
$\mathrm{SC}$, however, remains unclear, with no discernible trend (Miller et al., 2001; Scollan et al., 2003). Also, in the current study, the proportions of ALA, PA, and linoleic acid $(\mathrm{C} 18: 2$ cis-9,12) in herbage were consistent with values reported previously for ryegrass-based herbage (Bauchart et al., 1984; Palladino et al., 2009).

\section{Time of Feed Allocation and Intake, Milk Production, and Milk Composition}

Daily herbage intake was similar among treatments; these findings agree with those reported for earlylactating (Pulido et al., 2015) and mid-lactating dairy cows (Orr et al., 2001; Abrahamse et al., 2009) grazing a perennial ryegrass-based pasture either in the morning or the afternoon. These authors found no difference in daily herbage DMI in morning versus afternoon allocation of a new strip of pasture. In the present study, although estimates of herbage DMI were similar among treatments, daily milk, milk fat, and milk protein yields increased by $7 \%(+0.9 \mathrm{~kg} / \mathrm{d}), 9 \%(+57 \mathrm{~g} / \mathrm{d})$, and $8 \%$ $(+40 \mathrm{~g} / \mathrm{d})$, respectively, by offering p.m. versus a.m. forage. Consistent with our findings, Orr et al. (2001) reported a $5 \%$ increase in milk yields for cows moved to a new strip of pasture after afternoon milking. Gibb (2006) reported milk fat and milk protein concentrations from the experiment by Orr et al. (2001). Corresponding concentrations were increased by 4.7 and 0.4 $\mathrm{g} / \mathrm{kg}$, respectively, from cows on p.m., in broad agreement with our findings (1.2 and $0.4 \mathrm{~g} / \mathrm{kg}$, respectively). Although milk yields were similar, Abrahamse et al. (2009) reported increased fat- and protein-corrected milk yields from cows on p.m., generally attributable to greater milk fat concentrations.

Improving the nutritional quality of milk FA is becoming an increasing feature demanded by consumers, and enhancing the concentration of FA that are beneficial for human health could contribute to restore consumers' confidence in milk. Important targets remain reducing the amounts of medium-chain saturated FA and enhancing the contribution of MUFA (i.e., oleic acid and VA) and PUFA (RA and ALA) with known health benefits (e.g., Hebeisen et al., 1993; Hu et al., 1997). The quantity and quality of milk is related to the amount and quality of ingested herbage. In the present study, changing the time of feed allocation (and consequential herbage FA profile offered) altered the FA profile of milk (Table 4). Although a relatively small number of milk FA were altered by means of allocation time, the greater contribution of RA and total PUFA in milk of cows on a.m. herbage is significant and most likely attributable to a greater contribution of C18 precursors in a.m. herbage (largely ALA; Table 1). Rumen microorganisms and postingestive desaturation activity metabolize most dietary PUFA via complex processes. The concentration of PUFA in milk from grazing cows can be enhanced by increasing the amount or concentration of $\mathrm{C} 18$ precursors in the diet, by reducing the extent of ruminal biohydrogenation, or by increasing the mammary gland enzymatic activity of the $\Delta-9$ desaturase complex (i.e., the desaturation of VA into RA). Enhancing the amount or concentration of dietary precursors is most likely the contributing factor to greater RA and PUFA in milk from cows on a.m. herbage.

The strong linear relationship between the overall concentrations of RA and VA in milk [RA (g/100 FA) $\left.=0.42 \times \mathrm{VA}(\mathrm{g} / 100 \mathrm{FA})+0.18 ; \mathrm{R}^{2}=0.47\right]$, consistent with the precursor-product relationship, with VA/RA within 2 to 2.5 (Elgersma et al., 2006) (2.2 and 2.3 for milk from a.m. and p.m. herbage, respectively), were also seen in our study. Also, similar OBCFA concentrations among allocation treatments are in agreement with similar duodenal flows of OBCFA offered perennial ryegrasses manipulated for divergent SC:N ratios $(+\mathrm{SC} /-\mathrm{N}$ vs. $-\mathrm{SC} /+\mathrm{N})$ offered as sole diets (Doreau et al., 2007).

The greater concentrations of RA, total MUFA and PUFA (largely at the expense of saturated FA), and total FA $(\mathrm{mg} / \mathrm{mL})$ were realized in milk collected following the a.m. grazing period (i.e., afternoon milking) compared with milk collected following the p.m. allocation period (i.e., morning milking). In overall agreement with our findings, a recent comparison across conventional and organic grazing systems showed greater concentrations of VA, RA, and OBCFA and lesser concentrations of saturated FA up to $16 \mathrm{C}$ in milk collected during the afternoon compared with milk collected during the morning milking (Schwendel et al., 2015). In addition to changes in the FA profile of ingested herbage and grazing behavior (varying herbage disappearance rates in particular, as discussed below), changes in the FA profile of milk may also be attributable to the time since previous milking. In the current experiment, 8 and $16 \mathrm{~h}$ elapsed between morning and afternoon milking, respectively, but the effect of different milking intervals on the FA profile of milk remains largely unknown.

Several grazing management strategies including differences in HM offered (Stanton et al., 1997), herbage allowance (Bargo et al., 2006), time spent at pasture (Khanal et al., 2008), harvesting date and harvesting interval (Dewhurst et al., 2001), and N application rates (Elgersma et al., 2005) have been explored. But less is known about the effects of timing of fresh forage allocation (and corresponding milking time) on the FA profiles in milk. Pasture management plays an important role in forage FA composition, and quantifying the 
composition of FA in herbage in response to grazing management strategies can aid in the design of grazing strategies to increase precursors of beneficial FA in dairy products.

\section{Time of Feed Allocation and N Partition}

Consistent with our findings, Abrahamse et al. (2009) reported similar MUN concentrations among allocation treatments. Changes in milk and blood urea $\mathrm{N}$ concentrations have been associated with ammonia $\mathrm{N}$ concentration in the rumen (Jonker et al., 1998). Further, changes in ruminal ammonia $\mathrm{N}$ concentrations were quickly observable in MUN (Gustafsson and Palmquist, 1993), suggesting that an improved balance in the supply of energy from nonstructural carbohydrates and $\mathrm{N}$ leading to reduced ruminal ammonia $\mathrm{N}$ concentrations influences excretion of urea $\mathrm{N}$ in milk. However, the improved WSC to $\mathrm{CP}$ ratio provided by the p.m. herbage may not have been sufficient to elicit a significant response in $\mathrm{N}$ excretion, as was evidenced by similar MUN concentration and estimates of urinary $\mathrm{N}$ losses (g/d). Nonetheless, the amount of $\mathrm{N}$ secreted in milk tended to be greater for cows on p.m., and $\mathrm{N}$ utilization efficiency ( $\mathrm{N}$ in milk expressed as a proportion of $\mathrm{N}$ intake) increased by $18 \%$ by offering p.m. versus a.m. herbage. Together, these findings suggest an overall improvement in $\mathrm{N}$ utilization from cows on p.m. herbage.

Although timing of pasture allocation resulted in similar estimates of $\mathrm{N}$ partitioning toward urine ( $\mathrm{g}$ of $\mathrm{N} / \mathrm{d}$ ), $\mathrm{N}$ concentrations in urine ( $\mathrm{g}$ of $\mathrm{N} / \mathrm{L}$ ) were greater for cows on a.m. herbage. The reduced urinary $\mathrm{N}$ concentrations from cows on p.m. herbage is most likely to be attributable to differences in N and WSC concentrations in the herbage. In a multivariate context, Pacheco et al. (2010) reported that the urinary $\mathrm{N}$ concentration was inversely related to the DCAD $(\mathrm{mEq} / \mathrm{kg}$ of $\mathrm{DM})$ and the WSC concentration of the herbage consumed. Also, despite a significant reduction in urinary $\mathrm{N}$ concentration in one of the forages tested (a tetraploid Italian ryegrass L. multiflorum) compared with 2 diploid ryegrasses, the total amount of $\mathrm{N}$ excreted $(\mathrm{g} / \mathrm{d})$ did not differ among grasses (Pacheco et al., 2010). In our study, although dietary cation-anion difference, a measure of the difference between cations ( $\mathrm{Na}$ and $\mathrm{K}$ ) and anions ( $\mathrm{S}$ and $\mathrm{Cl}$ ) in herbage, did not differ, the WSC concentration in herbage was lesser for a.m. herbage. Dilution or concentration of $\mathrm{N}$ in urine by increasing or decreasing urine volumes and the number of urination events could also be partly responsible, but urine volumes and number of urination events were not measured in our study. Last, urinary creatinine and
MUN concentrations did not differ among allocation treatments (Equations [3] and [4], respectively).

In addition to total $\mathrm{N}$ excretion, high concentrations of urinary $\mathrm{N}$ in the urine patch in soil contributes substantially to the environmental impact of pastoral dairying. Further, manipulation of urinary N concentration $(\mathrm{g} / \mathrm{L})$ has been proposed as a means for reducing livestock greenhouse gas emissions from dairying in New Zealand (Ledgard et al., 2007). In the present study, both the effects of time of herbage allocation and time of sampling had a considerable effect on urinary $\mathrm{N}$ concentration and are important aspects to consider in the design of grazing strategies that target sustainable livestock emissions. Urinary $\mathrm{N}$ concentrations presented herein are in agreement with those reported by Pacheco et al. (2010) for dairy cows grazing ryegrass-based pastures in autumn.

\section{Time of Feed Allocation and Grazing Behavior}

With dairy cows grazing temperate pastures, the longest and most intense grazing events occur at dusk, and these events are often associated with a greater intake rate at this time of the day (Orr et al., 2001). In addition, it has been widely reported that most of the daily consumption of herbage by nonsupplemented grazing dairy cows occurs during daylight hours and that the proportion of time spent grazing is often greatest following the allocation of cows to a fresh strip of pasture (Abrahamse et al., 2009; Gregorini et al., 2009a). In the present study, total grazing time by cows on the a.m. treatment increased by $6 \%(+30 \mathrm{~min})$, with more of the grazing activity occurring during daylight hours (84 vs. $72 \%$ of total grazing time). However, cows on a.m. herbage spent more time grazing during the first $4 \mathrm{~h}$ after morning milking, but the time spent grazing after afternoon milking remained similar among treatments. Although estimates of daily herbage DMI were similar among a.m. and p.m. cows, the above findings, along with a different herbage disappearance rate (per hour), suggest that the temporal pattern of intake differed among allocation treatments. Cows given a new pasture strip in the afternoon obtained more of their herbage DMI in the evening, when herbage WSC concentrations were greater and $\mathrm{CP}$ concentrations were lesser (Table $2)$.

In similar experimental setups, Orr et al. (2001) and Abrahamse et al. (2009) reported a similar intake pattern for dairy cows allocated to either a.m. or p.m. herbage. These authors reported that cows allocated to a.m. herbage tended to have lower bite masses in the afternoon, but greater effects (even lower bite masses) were observed for cows on p.m. grazing in the morning. 
These findings are consistent both with an effect of sward depletion as the hours of grazing progressed beyond the main grazing event and with the greater rate of HM disappearance by cows allotted to fresh p.m. herbage. Because the quantity of herbage DM a grazing animal can prehend at any given bite represents a small fraction of the total daily requirement, reductions in bite size caused by adverse sward conditions must be compensated if daily intake is to be maintained. Attempts to compensate for reductions in bite size are often performed via increased grazing time (i.e., cows on a.m.) or increased biting rate (i.e., cows on p.m.). Assuming that more than $70 \%$ of the daily intake of herbage from pasture occurs within the first 3 to $4.5 \mathrm{~h}$ of grazing a new allocation (Trevaskis et al., 2004; Gregorini et al., 2009a), grazing in the afternoon equated to a greater proportion of herbage DMI at greater OM and WSC concentrations in concordance with lesser CP and NDF concentrations.

\section{CONCLUSIONS}

Despite similar partitioning of $\mathrm{N}$ toward urine, given similar amounts of herbage allocation, a simple change in management practice such as allocating a strip later in the day resulted in moderate increases in $\mathrm{N}$ captured in milk and in milk solids yields in late-lactation dairy cows. Pasture management plays an important role in forage FA composition, and quantifying the composition of FA in herbage in response to grazing management strategies can aid in the design of grazing strategies to increase precursors of beneficial FA in dairy products. A greater concentration of precursor FA in a.m. herbage resulted in a greater concentration of RA and PUFA in milk, compared with cows on p.m. herbage. These benefits, plus a lower concentration of saturated FA, however, were realized in milk collected during the afternoon milking compared with the morning milking.

\section{ACKNOWLEDGMENTS}

Project funded by Pastoral 21 (Feeds platform) and the Foundation for Research, Science and Technology (Contract 10X0604). The authors thank the staff at No. 4 Dairy Farm at Massey University for assistance during the trial; Michael Agnew (AgResearch) for herbage fatty acid analysis; and Arjan Jonker, John Koolaard, and Catherine McKenzie (AgResearch) for their valuable contributions.

\section{REFERENCES}

Abrahamse, P. A., S. Tamminga, and J. Dijkstra. 2009. Effect of daily movement of dairy cattle to fresh grass in morning or afternoon on intake, grazing behaviour, rumen fermentation and milk production. J. Agric. Sci. 147:721-730.

Bargo, F., J. E. Delahoy, G. F. Schroeder, and L. D. Muller. 2006. Milk fatty acid composition of dairy cows grazing at two pasture allowances and supplemented with different levels and sources of concentrate. Anim. Feed Sci. Technol. 125:17-31.

Bargo, F., L. D. Muller, E. S. Kolver, and J. E. Delahoy. 2003. Invited review: Production and digestion of supplemented dairy cows on pasture. J. Dairy Sci. 86:1-42.

Bauchart, D., R. Verite, and B. Remond. 1984. Long-chain fatty acid digestion in lactating cows fed fresh grass from spring to autumn. Can. J. Anim. Sci. 64:330-331.

Brito, A. F., G. F. Tremblay, A. Bertrand, Y. Castonguay, G. Belanger, R. Michaud, H. Lapierre, C. Benchaar, H. V. Petit, D. R. Ouellet, and R. Berthiaume. 2008. Alfalfa cut at sundown and harvested as baleage improves milk yield of late-lactation dairy cows. J. Dairy Sci. 91:3968-3982.

Burns, J. C., H. F. Mayland, and D. S. Fisher. 2005. Dry matter intake and digestion of alfalfa harvested at sunset and sunrise. J. Anim. Sci. 83:262-270

Ciavarella, T. A., R. J. Simpson, H. Dove, B. J. Leyry, and I. M. Sims. 2000. Diurnal differences in the concentration of water-soluble carbohydrates in Phalaris aquatica L. pasture in spring, and the effect of short-term shading. Aust. J. Agric. Res. 51:749-756.

Corson, D. C., G. C. Waghorn, M. J. Ulyatt, and J. Lee. 1999. NIRS: Forage analysis and livestock feeding. Proc. N. Z. Grassl. Assoc. 61:127-132.

Cosgrove, G. P., J. L. Burke, A. F. Death, M. J. Hickey, D. Pacheco, and G. A. Lane. 2007. Ryegrasses with increased water soluble carbohydrate: Evaluating the potential for grazing dairy cows in New Zealand. Proc. N. Z. Grassl. Assoc. 69:179-185.

Cosgrove, G. P., J. Koolaard, D. Luo, J. L. Burke, and D. Pacheco. 2009. The composition of high sugar ryegrasses. Proc. N. Z. Grassl. Assoc. 71:187-193.

Delagarde, R., J. L. Peyraud, L. Delaby, and P. Faverdin. 2000. Vertical distribution of biomass, chemical composition and pepsincellulase digestibility in a perennial ryegrass sward: Interaction with month of year, regrowth age and time of day. Anim. Feed Sci. Technol. 84:49-68.

Dewhurst, R. J., N. D. Scollan, S. J. Youell, J. K. S. Tweed, and M. O. Humphreys. 2001. Influence of species, cutting date and cutting interval on the fatty acid composition of grasses. Grass Forage Sci. 56:68-74.

Doreau, M., D. Rearte, J. Portelli, and J. L. Peyraud. 2007. Fatty acid ruminal metabolism and digestibility in cows fed perennial ryegrass. Eur. J. Lipid Sci. Technol. 109:790-798.

Elgersma, A. 2015. Grazing increases the unsaturated fatty acid concentration of milk from grass-fed cows: A review of the contributing factors, challenges and future perspectives. Eur. J. Lipid Sci. Technol. 117:1345-1369.

Elgersma, A., P. Maudet, I. M. Witkowska, and A. C. Wever. 2005. Effects of nitrogen fertilisation and regrowth period on fatty acid concentrations in perennial ryegrass (Lolium perenne L.). Ann. Appl. Biol. 147:145-152.

Elgersma, A., S. Tamminga, and G. Ellen. 2006. Review-Modifying milk composition through forage. Anim. Feed Sci. Technol. 131:207-225

Ellis, J. C., A. Bannink, J. Dijkstra, A. J. Parsons, S. Rasmussen, G. R. Edwards, E. Kebreab, and J. France. 2009. The effect of high sugar grass on nitrogen and methane output in cattle: A modeling approach. J. Dairy Sci. 92(E-Suppl. 1):109. (Abstr.)

Fisher, D. S., H. F. Mayland, and J. C. Burns. 1999. Variation in ruminants' preference for tall fescue hays cut either at sundown or at sunup. J. Anim Sci. 77:762-768.

Gibb, M. J. 2006. Grassland management with emphasis on grazing behaviour. Pages 141-157 in Fresh Herbage for Dairy Cattle: The Key to a Sustainable Food Chain. A. Elgersma, J. Dijkstra, and S. Tamminga, ed. Wageningen UR Frontis Series 18, Dordrecht, the Netherlands. 
Gibb, M. J., C. A. Huckle, and R. Nuthall. 1998. Effect of time of day on grazing behaviour by lactating dairy cows. Grass Forage Sci. $53: 41-46$

Glasser, F., M. Doreau, G. Maxin, and R. Baumont. 2013. Fat and fatty acid content and composition of forages: A meta-analysis. Anim. Feed Sci. Technol. 185:19-34.

Gregorini, P. 2012. Diurnal grazing pattern: Its physiological basis and strategic management. Anim. Prod. Sci. 52:416-430.

Gregorini, P., C. E. Clark, J. G. Jago, C. B. Glassey, K. L. McLeod, and A. J. Romera. 2009a. Restricting time at pasture: Effects on dairy cow herbage intake, foraging behavior, hunger-related hormones, and metabolite concentration during the first grazing session. J. Dairy Sci. 92:4572-4580.

Gregorini, P., S. A. Gunter, and P. A. Beck. 2008. Matching plant and animal processes to alter nutrient supply in strip-grazed cattle: Timing of herbage and fasting allocation. J. Anim. Sci. 86:10061020.

Gregorini, P., K. J. Soder, M. A. Sanderson, and G. R. Ziegler. 2009b. Toughness, particle size and chemical composition of meadow fescue (Festuca pratensis Hud.) herbage as affected by time of day. Anim. Feed Sci. Technol. 151:330-336.

Griggs, T. C., J. W. MacAdam, H. F. Mayland, and J. C. Burns. 2005 Nonstructural carbohydrate and digestibility patterns in orchardgrass swards during daily defoliation sequences initiated in evening and morning. Crop Sci. 45:1295-1304.

Gustafsson, A. H., and D. L. Palmquist. 1993. Diurnal variation of rumen ammonia, serum urea, and milk urea in dairy cows at high and low yields. J. Dairy Sci. 76:475-484.

Hebeisen, D. F., F. Hoeflin, H. P. Reusch, E. Junker, and B. H. Lauterburg. 1993. Increased concentrations of omega-3 fatty acids in milk and platelet rich plasma of grass-fed cows. Int. J. Vitam. Nutr. Res. 63:229-233.

Holmes, C. W., I. M. Brookes, D. J. Garrick, D. D. S. Mackenzie, and G. F. Wilson. 2003. Milk Production from Pasture. Massey University, Palmerston North, New Zealand.

Hu, F. B., M. J. Stampfer, J. E. Manson, E. Rimm, G. A. Colditz, B. A. Rosner, C. H. Hennekens, and W. C. Willett. 1997. Dietary fat intake and the risk of coronary heart disease in women. N. Engl. J. Med. 337:1491-1499.

Jonker, J. S., R. A. Kohn, and R. A. Erdman. 1998. Using milk urea nitrogen to predict nitrogen excretion and utilization efficiency in lactating dairy cows. J. Dairy Sci. 81:2681-2692.

Khanal, R. C., T. R. Dhiman, and R. L. Boman. 2008. Changes in fatty acid composition of milk from lactating dairy cows during transition to and from pasture. Livest. Sci. 114:164-175.

Ledgard, S. F., B. G. Welten, J. C. Menneer, K. Betteridge, J. R. Crush, and M. D. Barton. 2007. New nitrogen mitigation technologies for evaluation in the lake Taupo catchment. Proc. N. Z. Grassl. Assoc. 69:117-121.

Macdonald, K. A., J. W. Penno, J. A. S. Lancaster, and J. R. Roche. 2008. Effect of stocking rate on pasture production, milk production, and reproduction of dairy cows in pasture-based systems. J. Dairy Sci. 91:2151-2163.

Macoon, B., L. E. Sollenberger, J. E. Moore, C. R. Staples, J. H. Fike, and K. M. Portier. 2003. Comparison of three techniques for estimating the forage intake of lactating dairy cows on pasture. J. Anim. Sci. 81:2357-2366.

Mayland, H. F., D. M. Mertens, T. Taylor, J. C. Burns, D. S. Fisher, P. Gregorini, T. Ciavarella, K. Smith, G. Shewmaker, and T. Griggs. 2005. Diurnal changes in forage quality and their effects on animal preference, intake, and performance. Pages $12-20$ in Proceedings of the California Alfalfa Symposium. UC Cooperative Extension, University of California, Davies.

Miller, L. A., J. M. Moorby, D. R. Davies, M. O. Humphreys, N. D. Scollan, J. C. MacRae, and M. K. Theodorou. 2001. Increased concentration of water-soluble carbohydrate in perennial ryegrass (Lolium perenne L.): Milk production from late-lactation dairy cows. Grass Forage Sci. 56:383-394.

Orr, R. J., S. M. Rutter, P. D. Penning, and A. J. Rook. 2001. Matching grass supply to grazing patterns for dairy cows. Grass Forage Sci. 56:352-361.

Ørskov, E. R., and I. McDonald. 1979. The estimation of protein degradability in the rumen from incubation measurements weighted according to the rate of passage. J. Agric. Sci. 92:499-503.

Pacheco, D., J. L. Burke, and G. P. Cosgrove. 2007. An empirical model to estimate efficiency of nitrogen utilization in cows grazing fresh forages. Pages 409-416 in Meeting the Challenges for Pasture-Based Dairying. Proc. Australasian Dairy Sci. Symp., Melbourne, Australia.

Pacheco, D., K. Lowe, M. J. Hickey, J. L. Burke, and G. P. Cosgrove. 2010. Seasonal and dietary effects on the concentration of urinary $\mathrm{N}$ from grazing dairy cows. Pages $68-71$ in Meeting the Challenges for Pasture-Based Dairying, Lincoln, New Zealand, Lincoln University, Christchurch, New Zealand. G. R. Edwards and R. H. Bryant, ed. Proc. Australasian Dairy Sci. Symp., Christchurch, New Zealand.

Palladino, R. A., M. O’Donovan, E. Kennedy, J. J. Murphy, T. M Boland, and D. A. Kenny. 2009. Fatty acid composition and nutritive value of twelve cultivars of perennial ryegrass. Grass Forage Sci. 64:219-226.

Peyraud, J. L., and L. Astigarraga. 1998. Review of the effect of nitrogen fertilization on the chemical composition, intake, digestion and nutritive value of fresh herbage: Consequences on animal nutrition and N balance. Anim. Feed Sci. Technol. 72:235-259.

Pulido, R. G., M. Ruiz-Albarrán, O. A. Balocchi, P. Nannig, and F. Wittwer. 2015. Effect of timing of pasture allocation on production, behavior, rumen function, and metabolism of early lactating dairy cows during autumn. Livest. Sci. 177:43-51.

Schwendel, B. H., P. C. H. Morel, T. J. Wester, M. H. Tavendale, C. Deadman, B. Fong, N. M. Shadbolt, A. Thatcher, and D. E. Otter. 2015. Fatty acid profile differs between organic and conventionally produced cow milk independent of season or milking time. J. Dairy Sci. 98:1411-1425.

Scollan, N. D., M. R. F. Lee, and M. Enser. 2003. Biohydrogenation and digestion of long chain fatty acids in steers fed on Lolium perenne bred for elevated levels of water-soluble carbohydrate. Anim. Res. 52:501-511.

Stanton, C., F. Lawless, G. Kjellmer, D. Harrington, R. Devery, J. F. Connolly, and J. Murphy. 1997. Dietary influences on bovine milk cis-9,trans-11-conjugated linoleic acid content. J. Food Sci 62:1083-1086

Sukhija, P. S., and D. L. Palmquist. 1988. Rapid method for determination of total fatty acid content and composition of feedstuffs and feces. J. Agric. Food Chem. 36:1202-1206.

Taweel, H. Z., B. M. Tas, H. J. Smit, A. Elgersma, J. Dijkstra, and S. Tamminga. 2006. Grazing behaviour, intake, rumen function and milk production of dairy cows offered Lolium perenne containing different levels of water-soluble carbohydrates. Livest. Sci. 102:33-41.

Toledo, P., A. Andren, and L. Bjorck. 2002. Composition of raw milk from sustainable production systems. Int. Dairy J. 12:75-80.

Trevaskis, L. M., W. J. Fulkerson, and K. S. Nandra. 2004. Effect of time of feeding carbohydrate supplements and pasture on production of dairy cows. Livest. Prod. Sci. 85:275-285.

Vlaeminck, B., V. Fievez, A. R. J. Cabrita, A. J. M. Fonseca, and R. J. Dewhurst. 2006. Factors affecting odd- and branched-chain fatty acids in milk: A review. Anim. Feed Sci. Technol. 131:389-417. 